\title{
Slovenian Friars Minor's Efforts for Dialogue with Muslims
}

\author{
Mari Jože Osredkar* \\ https://doi.org/10.31192/np.19.2.2 \\ mari.osredkar@teof.uni-lj.si. \\ UDK / UDC: 27-789.32(497.4):28 \\ https://orcid.org/0000-0002-5902-6171 \\ Pregledni članak / Review \\ Primljeno / Received: 9. veljače 2021. / Feb 9, 2021 \\ Prihvaćeno / Accepted: 12. svibnja 2021. / May 12, 2021
}

The point of departure of the article are the Catholic theological foundations for interreligious dialogue written at the Second Vatican Council. The documents of the last church Council encourage Pope Francis to imitate the Poor from Assisi, whose name he chose when he was elected Pope. On the occasion of his visit to Abu Dhabi, for the first time after the conquests of Islam, he celebrated Holy Mass on the Arabian Peninsula and assured Muslim leaders that he was coming to visit them as a brother. He signed a document on world fraternity with the great Iman of the Egyptian Islamic University, in which they wrote that everyone, Christians and Muslims, is created as a child of God. They invite people to respect each other and work for peace despite their differences. The initiator of the dialogue between Friars Minor and the Muslims is Francis of Assisi, who 800 years ago held a peaceful meeting with Sultan Al-Kamil in Damietta, Egypt, in an atmosphere of respect and mutual acceptance. The purpose of our work is however to introduce the actual efforts of the Slovenian Franciscans for Dialogue with Muslims.

Keywords: Interreligious dialogue, dialogue between Christians and Muslims, Francis of Assisi, Pope Francis, Slovenian Franciscans.

\footnotetext{
* Mari Jože Osredkar, PhD, Assist. Prof., University of Ljubljana, Faculty of Theology; Address: Poljanska 4, SI-1000 Ljubljana, Slovenia.
} 


\section{Introduction}

Before exploring in depth, the subject of our essay, we introduce two basic concepts that underlie our discussion. The Friars Minor are a Catholic Religious Order also called the Franciscans, the Franciscan Order, or the Seraphic Order with the postnominal abbreviation OFM. They are one of the three branches of the First Order, founded in 1210 by Francis of Assisi, Two others are the Capuchin and the Conventual Orders. The second concept underscoring this essay is Friars Minor's efforts for promoting dialogue with Muslims. Thus, here the meaning of interreligious dialogue derives from Catholic theology. This dialogue is the communication, between Friars Minor and members of Islamic religion, which allows both groups to coexist. In fact, it means that Franciscans accept Muslims as brothers, with all respect possible.

The article is divided into four chapters. In Chapter one, we examine the Catholic doctrine of interreligious dialogue derived from Church documents. Chapter two focuses on the meeting between Saint Francis and the sultan of Egypt as a symbolic beginning of the modern dialogue between Friars Minor and Muslims. Chapter three deals with the efforts of Pope Francis to create and sustain dialogue between Christians and Muslims. Officially, the Pope is not a Franciscan; however, his choice of the name Francis and his commitment to dialogue reveal that he leads the Church in the spirit of Saint Francis of Assisi. Finally, we detail in Chapter four present-day collaboration between Slovenian Franciscans and Muslims.

\section{Catholic Theological Basis of the Interreligious Dialogue with Muslims}

In August1964, shortly after the election of Giovani Battista Montini to the throne of the Apostle Peter, Pope Paul VI ${ }^{1}$ wrote his first encyclical Ecclesiam suam. In this document, the Pope set the starting point of the actual Catholic doctrine of dialogue with those who think differently from Catholics and, above all, with those whose faith differs from the Christian one:

»But we do not wish to turn a blind eye to the spiritual and moral values of the various non-Christian religions, for we desire to join with them in promoting and defending common ideals in the spheres of religious liberty, human brotherhood, education, culture, social welfare, and civic order. Dialogue is possible in all these great projects, which are our concern as much as theirs and we will

\footnotetext{
${ }_{1}$ Giovani Battista Enrico Antonio Maria Montini was elected Pope Paul VI. the November 4, 1963.
} 
not fail to offer opportunities for discussion in the event of such an offer being favorably received in genuine, mutual respect. «

From this definition of interreligious dialogue, the Second Vatican Ecumenical Council Fathers later wrote that the Church's primary task is to strive for unity and love between people and thus between nations, since all nations are one community and have the same origins from God. ${ }^{3}$ The Church's attitude and the Catholic doctrine of interreligious dialogue were made possible by the document Dogmatic Constitution on the Church. Until the Second Vatican Ecumenical Council, the principle Extra ecclesiam nulla salus was interpreted literally. It guaranteed eternal life in heaven to those who were baptized in the Catholic Church. However, in Dogmatic Constitution on the Church we find a new interpretation of the former principle:

»Those who, through no fault of their own, do not know the Gospel of Christ or his Church, but who nevertheless seek God with a sincere heart, and, moved by grace, try in their actions to do his will as they know it through the dictates of their conscience, may too achieve eternal salvation. $^{4}$

Thus, for the first time, the Catholic Church acknowledged that even in nonChristian religions, people believe in God. In addition, there are even more parallels than that. Catholic theology at the same time recognized the possibility of salvation for non-Catholics and for non-Christians. These two documents, Ecclesiam suam and Dogmatic Constitution on the Church, enabled the enactment of the conciliar document Declaration on the Relation of the Church to Non-Christian Religions, which is the heart of conciliar Catholic theology on interreligious dialogue. By enabling the salvation of all people, the Church laid the foundation for dialogue with members of other religions while giving credibility to the Declaration on the Relation of the Church to Non-Christian Religions document. In the Dogmatic Constitution on the Church, the Church does not claim that other religions possess the full truth, but they seek to find common ground in other faiths and to build dialogue on those points that connect the two different faiths. Redemption is accessible to Muslims too, as they, like Catholics, profess the Abrahamic faith and worship the only, merciful God who will ultimately judge all of humanity. Declaration on the Relation of the Church to Non-Christian Religions encouraged believers to participate with people of other religions. They acknowledged that there are truths in other religions that are sacred and must be respected:

»The Catholic Church rejects nothing that is true and holy in these religions. The Church regards with sincere reverence those ways of conduct and of life,

2 PAUL VI, Ecclesiam suam (6.VIII.1964), Roma, Curia Romana, 1965, no. 108.

${ }^{3}$ Cf. SECOND VATICAN COUNCIL, Declaration on the Relation of the Church to Non-Christian Religions (28.X.1965), no. 1.

${ }^{4}$ SECOND VATICAN COUNCIL, Dogmatic Constitution on the Church (21.XI.1964), no. 16. 
those precepts and teachings which, though differing in many aspects from the ones she holds and sets forth, nonetheless often reflect a ray of that Truth which enlightens all men. $\aleph^{5}$

Catholics must be prepared and open to dialogue with members of other religions. Through understanding and love, they must accept, respect and maintain the spiritual, moral and socio-cultural values found in other religions. Indeed, the Church proclaims, and ever must proclaim Christ »the way, the truth, and the life " (John 14:6), in whom men may find the fullness of religious life, in whom God has reconciled all things to Himself. ${ }^{6}$ The Church pointed to the possibility of building interreligious dialogue on the similarities between the Christian and Muslim faiths. ${ }^{7}$ The Church urged its believers to maintain peace with all people, as it would be the only way they would show respect and love for God. She condemned any violence, neglect, or intolerance of Christians against people of other faiths and cultures:

"Since in the course of centuries not a few quarrels and hostilities have arisen between Christians and Muslims, this sacred synod urges all to forget the past and to work sincerely for mutual understanding and to preserve as well as to promote together for the benefit of all mankind social justice and moral welfare, as well as peace and freedom. ${ }^{8}$

The Declaration on the Relation of the Church to Non-Christian Religions laid the foundation for the dialogical path of the Catholics who have the courage to live according to the Gospel. Interreligious dialogue, moreover, was not the invention of the Council Fathers fifty plus years ago. The pursuit of unity is the commandment of Jesus Christ, who wanted all to be one; God's Son set the command of love for His neighbor and instructed his disciples to do good to their enemies and to accept them, even though they are different. Friars minor were aware of this many centuries ago.

\section{The Beginning of Dialogue between Friars Minor and Muslims 800 Years Ago}

Saint Francis, on several occasions, sought to take the Gospel out of Italy. In 1212, he set sail for Syria through the Adriatic Sea, but the ship had to dock on the Dalmatian coast due to inclement weather. A few years later, Francis wanted to go to Morocco, but an illness prevented him from traveling. His third attempt was successful. He arrived in Egypt in July 1219. The Franciscan

\footnotetext{
${ }^{5}$ SECOND VATICAN COUNCIL, Declaration on the Relation of the Church to Non-Christian Religions (28.X.1965), no. 2.

${ }^{6}$ Cf. ibid.

7 Cf. ibid, no. 3.

${ }^{8}$ Ibid.
} 
and foreign sources ${ }^{9}$ talk about his meeting with the Sultan in Damietta, but the testimonies are not consistent with each other. Biographies of Francis written by Franciscan Brothers Thomas Celano ${ }^{10}$ and St. Bonaventure ${ }^{11}$ speak of Francis' desire for martyrdom ${ }^{12}$. Everyone in turn is of the opinion that Francis approached the Sultan with the desire to receive a martyr's death. Nevertheless, Giordano of Gian, a contemporary of Francis, points out that Francis did not seek martyrdom in the meeting with the Sultan. Bishop Jacob of Vitry ${ }^{13}$ (1170-1240), who closely followed the events of the battles at Damietta, wrote the same. A text written in 1220 describes Francis' visit to the Sultan. It mentions that Francis preached the Word of God there, but with little success. Beyond any desire of Francis for martyrdom, these commentaries emphasize that Francis promoted a proclamation of peace ${ }^{14}$. The description of the Sultan is much more positive in the text of Bishop Jacob than in the official biographies of Francis. In any case, all of the above-mentioned authors presented Francis as a man of peace. On the other side, the Crusaders were looking for a solution to the wars to be fought with their arms.

From the report of Bishop Jacob, we learn that the Crusaders contemporary with Francis led the way to the Fifth Crusade through Egypt. From there, they wanted to continue the journey towards Jerusalem to conquer it again because it was then in Saracen hands. The Crusaders disembarked on the left bank of the Nile River on May 29, 1218. As early as August 24 of that year, they occupied the tower in front of the city of Damietta, where their advance towards Jerusalem stopped. When the Christian and Muslim armies stood against each other for some time, Malik al-Kamil, who became sultan in 1219, repeatedly offered peacekeepers to the Crusaders, but they did not accept them ${ }^{15}$. For a year, the battleline did not move. Francis, who arrived at the battleline in July 1219, wanted to persuade the Crusaders to accept the offered ceasefire, but Christian soldiers did not obey him. They also did not immediately satisfy Francis' desire to go talk to Sultan al-Malik al-Kamil. It was not until August 29, when the battle claimed many casualties on both sides, most notably the side of the Crusaders down by 6,000, that Cardinal Pelagius Galvan (d'Albano) allowed with a

\footnotetext{
9 Anna AJELLO, I fratti minori e il saraceni nel XIII secolo, in: San Francesco e il sultano, Firenze, Studi Francescani, 2011, 477.

${ }^{10}$ Thomas de CELANO, Vita sancti Francisci, in : Fontes franciscani, a cura di E. Menestó e S. Brufani, S. Maria degli Angeli, 1995, 273-424.

${ }^{11}$ Bonaventura, Legenda major s. Francisci, in : Saint François d'Assise, rassemblés et présentés par les PP. Théophile Desbonnets et Damien Vorreux O.F.M., Editions franciscaines, Paris, 1968, 565-577.

${ }^{12}$ Mary MELONE, Il desiderio di martirio de Francesco d'Assisi nella legenda maior di Bonaventura da Bagnoregio, in: San Francesco e il sultano, Firenze, Studi Francescani, 2011, 509-524.

${ }^{13}$ Italian literature calls him »Giacomo di Vitry, vescovo di San Giovanni d'Acri«, because in 1216 he was ordained a bishop of Accra (Akkon), Syria.

${ }^{14}$ John TOLAN, Il santo dal sultano, Bari, Editori Laterza, 2009, 27.

${ }^{15}$ Ibid, 34-35.
} 
heavy heart Francis to visit the Sultan. The Cardinal emphasized that Francis was going at his own risk. ${ }^{16}$ According to the most widespread reports, Sultan al-Malik al-Kamil was born either in 573 or 576 according to the Arabic calendar, corresponding to the years 1177 and 1180 AD in the Christian calendar. He was born into a ruling family of the Ayubid dynasty, which was of Kurdish origin and was previously ruled by Saladin ${ }^{17}$. Francis did not know Sultan alMalik al-Kamil. In his consciousness, he had the goal of telling Muslims about the Gospel. To the Sultan's questions, the servant of God, Francis, answered with a courageous heart that he had not been sent by men, but by the supreme God, to show him and his people the way of salvation and to proclaim the Gospel of truth. In addition, »the Sultan who saw the admirable zeal of the spirit and the virtue of the man of God«, according to St. Bonavenura, »gladly listened to him $\aleph^{18}$. Francis wanted to proclaim Christ to Sultan Al-Malik, and thus to achieve the Sultan's conversion, which could be the path to peace. The meeting with the Sultan left a deep mark on Francis. Shortly thereafter (1221) in the Earlier Rule, he devoted the whole of Chapter 12 to »those who will go among the Saracens « with precise instructions on how the brothers should act there:

»Whoever should, by divine inspiration, wish to go among the Saracens and other infidels must ask permission from their provincial ministers. The ministers should grant permission only to those whom they consider qualified to be sent. $\ll^{19}$

Francis' approach to preaching is very respectful of Muslims. Francis is also considered to be the first full-time founder to include in his guide a chapter on the mission of Friars to Muslims. True respect is the basis of dialogue between members of different religions. The intentions of Saint Francis to meet Muslims are certainly not in context with the principles of interreligious dialogue of Catholic theology today. Francis' priority was to preach the Gospel. However, his meeting with the Sultan of Egypt can be regarded as the first known act of dialogue between Friars Minor and Muslims. Their meeting in fact was conceived in a peaceful manner. The content of their conversation is unknown. However, when they broke up, they both remained firm in their faith and parted peacefully.

\footnotetext{
${ }^{16}$ Manuel CORULLON, L'incontro tra Francesco d'Assisi e il Sultano, Milano, Edizioni biblioteca francescana, 2018, 24-34.

${ }^{17}$ Cf. Aljaž KRANJC, Mesto Al-Malika al-Kamila v zgodovini islama [The position of Al-Malik al-Kamil in the history of Islam], Edinost in dialog, 74 (2019) 2, 31-40, 38-39.

${ }^{18}$ Bonaventura, Legenda Major..., 671.

${ }^{19}$ The Rule of Saint Francis, chapter XII.
} 


\section{The Way of Interreligious Dialogue of Pope Francis}

Pope Francis immediately after his election in 2013 continued the practice of interreligious dialogue of his predecessors, but in his own way. In his efforts we recognize Saint Francis from Assisi whose name he chose for his pontificate. On the first days of February 2019, he visited the United Arab Emirates and celebrated a public holy mass in the Arabian Peninsula in Abu Dhabi where Sharia law was established. Pope Francis »consecrated bread and wine« on Muslim holy land. Much more, the Pope prayed for peace there with Muslims. Before attending the interreligious conference, he told his host, Crown Prince Sheikh Mohammed bin Zayed Al Nahyan, that the Pope was coming as a brother. $\mathrm{He}$ expressed his respect to the Muslims. Pope Francis in Abu Dhabi said during an interreligious conference at the Founder's Memorial Building:

"I am grateful to the Lord for the $800^{\text {th }}$ anniversary of the meeting between Saint Francis of Assisi and Sultan al-Malek-al-Kamil. I accepted the opportunity to come here as a believer, thirsty for peace, as a brother seeking peace with his brothers. To desire peace, to promote peace, to be an instrument of peace is why we are here. $\ll^{20}$

The highlight of the visit is a Document on the Human Brotherhood for World Peace and Common Coexistence signed by the Pope with the great Imam, Al Azhar. Let's just focus on one sentence of this document:

»The pluralism and the diversity of religions, color, sex, race and language are willed by God in His wisdom, through which He created human beings. This divine wisdom is the source from which the right to freedom of belief and the freedom to be different derive. Therefore, the fact that people are forced to adhere to a certain religion or culture must be rejected, as also the imposition of a cultural way of life that others do not accept. $\ll^{21}$

We could easily understand that the Pope and the Imam agreed that God allows some of us to be born as Christians and others to be Muslims! If we accept the plurality of religions in the same way as we accept the diversity of genders, nationalities and races, then we humans can truly give ourselves a disposition toward reconciliation by accepting and respecting all people as we participate in the modern world. That is precisely the purpose of the present Holy Father. He wants all people to be respected and accepted as children of the same God. Theology always responds to the needs of the time. ${ }^{22}$ Pope Francis' thinking is completely in line with the Gospel and Catholic teaching. As a Catholic, one

\footnotetext{
${ }^{20}$ Pope Francis, Konferenca, May 31, 2019: https://www.vaticannews.va/sl/papez/news/2019-02/ papez-francisek-abu-dhabi-medverska-konferenca.html.

${ }^{21}$ Pope Francis and Sheikh Ahmed el-Tayeb, Grand Imam of Al-Azhar, Document on Human Fraternity for World Peace and Living Together (Abu Dhabi, February 4, 2019).

${ }^{22}$ Robert PETKOVŠEK, Veselje resnice in svetopisemski monoteizem [The Joy of Truth and Biblical Monotheism], in: Edinost in dialog, 73 (2018) 1-2, 235-258, 237.
} 
cannot tell a Muslim that they are brothers, and that only a Catholic will go to heaven. It is also impossible to say that a Catholic was born in a Catholic family by God's will, however, a Muslim was born in a Muslim family by God's mistake. No, the Pope is right, even Muslims are born into Islamic families by God's will. The sentence in the document from Abu Dhabi is essentially the statement of Article 16 of the Dogmatic Constitution on the Church expressed by other words.

A month after, Pope Francis sent his delegate to Damietta, March 1, 2019. Cardinal Leonardo Sandri, the prefect of the Congregation for the Eastern Church, arrived in Egypt and shared the desire of Pope Francis to make every effort to promote peace and dialogue. For that occasion, the Holy Father wrote a special letter in which he called Saint Francis a »Man of Peace« who taught his brothers to say, »Let the Lord give you peace! $\aleph^{23}$ The Pope asked Cardinal Sandri to bring his brotherly greetings to all, Christians and Muslims. In the letter, moreover, he wishes that no one succumbed to the temptation of violence, especially under any religious pretense.

\section{Today's Cooperation between Slovenian Franciscans and Muslims}

Today, the Franciscans strive to continue and develop good relationships with their Muslim brothers. As faithful sons of Saint Francis and the Catholic Church, Franciscans are irrevocably committed to interreligious dialogue. They show with their lives that their beliefs are not only in words but also in actions. As people called to walk in Christ's footsteps, Franciscans embrace that same path of brotherhood so that, by a kind and reverent presence among both fellow Christians and the sincere members of other religions, they may increase the number of people God has given them. ${ }^{24}$

In the Franciscan Order, there is The Commission for Ecumenical and Interreligious Dialogue. Composed of the President and nine members from different countries, it meets to establish activities and projects, in support of the Order's General Constitutions ${ }^{25}$ and Ratio Studiorum ${ }^{26}$. In addition to this commission, there is the Order's special Commission for Dialogue with Islam. It is their job to prepare the development of pastoral and preaching aids and materials and programs designed to educate brothers of the Order about Islam

\footnotetext{
${ }^{23}$ Pope Francis, Epistula data Leonardo S.R.E. Cardinali Sandri, May 31, 2019: http://w2.vatican.va/content/francesco/la/letters/2019/documents/papa-francesco_20190226_lettera-card-sandri.html.

${ }^{24}$ Cf. General Constitutions, 95, $\$ 2$.

${ }^{25}$ General Constitutions, 95, \$\$1-2.

${ }^{26}$ Ratio Studiorum, 70-74.
} 
and to prepare them for engagement in the various forms of Catholic-Muslim dialogue, in support of the Order's General Constitutions ${ }^{27}$ and Ratio Studiorum $^{28}$.

At the initiative of the Order's special Commission for Dialogue with Islam, the General Minister of the Order of Franciscans, Fr. Michael A. Perry, invited Franciscans around the world in a special communique to remember the meeting of Francis and the Sultan through a variety of commemorative events. ${ }^{29}$ The response has been very encouraging. In 2019, Franciscans organized a number of events that remind us of the encounter of the Saint and the Sultan eight centuries ago and that evaluate the breadth and depth of interreligious dialogue occasioned by this meeting in 1219 . Slovenian Franciscans also joined the celebration. The Slovenian Franciscan Province of the Holy Cross and the Stanko Janežič Institute for Dogmatic, Fundamental and Ecumenical Theology and Religiology and Dialogue, operating within the Faculty of Theology in Ljubljana, organized a scientific conference on the 800 years of Convivence between Franciscans and Muslims. It took place October 1-3, 2019 in the Franciscan friary at Tromostovje in Ljubljana. The Conference highlighted the event of eight centuries ago and focused on the dialogue between Christians and Muslims in the past and today. The lecturers concentrated on cooperation between Franciscans and Muslims in the past eight centuries. In the sessions on interreligious dialogue, speaking about dialogue was not the most important thing, but creating occasions for dialogue. At the Ljubljana Symposium, nearly half of the participants were Muslim ${ }^{30}$. Christian professors have sought not to speak of Muslims but to speak to Muslims, with all respect. An honest conversation with them means that interreligious dialogue is alive.

Active interreligious dialogue for the Slovenian Franciscans has been mainly because of work and activities of Franciscan fr. Mari Osredkar, who is the head of The Stanko Janežič Institute for Dogmatic, Fundamental and Ecumenical Theology and Religiology and Dialogue. His dedication to the actualization of dialogue can be divided into three levels. On the first level, he talks to Muslims living in Slovenia ${ }^{31}$. Muslims have optimal Islamic identity because the Slove-

\footnotetext{
${ }^{27}$ General Constitutions, $95, \$ 3$.

${ }^{28}$ Ratio Studiorum, 70-74.

${ }^{29}$ Michael A. PERRY, Pismo generalnega ministra Reda manjših bratov ob 800. obletnici srečanja sv. Frančiška in sultana Malik al-Kamila, Poročila Slovenske frančiškanske province sv. Križa, 1 (2019) 7-9.

${ }^{30} 800$ Years of Convivence, International Scientific Conference on the Dialogue between Christians and Muslims at the $800^{\text {th }}$ Anniversary of the Meeting between Saint Francis of Assisi and the Sultan Al-Kamil in Egypt. October 1-3, 2019, Ljubljana, Slovenia.

${ }^{31}$ In Slovenia, slightly less than 50.000 citizens or $2.4 \%$ of the population registered at the 2002 census are Muslims. In 2020, they built a mosque and an Islamic cultural center in Ljubljana, where the mufti has his headquarters, which leads the work of 17 Islamic committees on Slovenian territory.
} 
nian state ensures religious freedom ${ }^{32}$. The efforts for interreligious dialogue of Osredkar on the first level can be seen in the regular meetings with the Mufti and Imams of the Islamic Community in Slovenia. In places where Islamic imams reside, he organizes meetings between them and Catholic pastors. At these meetings, imams and pastors get to know each other and make plans for how their believers could collaborate at the local level. Knowledge and cooperation are the foundation of dialogue and peaceful coexistence. Good relations can be maintained by even minor signs such as greetings for religious holidays. On the second level, there are the academic contacts of dr. Osredkar with Islamic faculties in different countries. Especially he maintains contacts with the Islamic Theological Faculty in Sarajevo, and at his initiative, the Faculty of Theology in Ljubljana has concluded an agreement on pedagogical and scientific cooperation. The fruit of this agreement has been a series of lectures given by Professor dr. Nedžad Grabus on Islamic subjects taught as part of a master's degree program Religion and Ethics at the Catholic Faculty of Ljubljana. This is the first time in the hundred-year history of the Catholic Theological Faculty in Ljubljana that an Islamic expert taught Catholic students. Osredkar is also affiliated with the Islamic Theological Faculty in Kutahya, Turkey. In 2015, through the Erasmus exchange, he lectured for a week to Muslim students at the Islamic Faculty of Theology in Kutahya. In 2019, Professor Ahmed Türkan came to teach Slovenian students at the Faculty of Theology in Ljubljana. Collaboration with Shia Muslims from Iran is a special chapter in the efforts for dialogue of dr. Mari Osredkar. With the help of the Embassy of the Islamic Republic of Iran in Ljubljana in 2015, he began a collaboration with the Center for Interreligious Dialogue in Tehran, which operates within the Ministry of Culture of the Islamic Republic of Iran. In December 13-17, 2015, a delegation of the Faculty of Theology in Ljubljana attended a conference on interreligious dialogue focusing on the role of religions in the fight against extremism and violence in today's world. The scientific meeting was organized by the Center for Interreligious Dialogue of Tehran. The delegation was led by dr. Mari Jože Osredkar and its members were dr. Tadej Strehovec, dr. Vojko Strahovnik, dr. Lenart Škof and dr. Bojan Žalec. As part of the conference, the delegation gave lectures at three different institutions. On December 14 was the first academic meeting at the Campus of Islamic Culture and Relations Organizations, Tehran. The delegation was received by the Director of the Center dr. Ali Mohammad Helmi, and the welcoming speech was delivered by the President of this Center, dr. Abuzar Ibrahimi. There were five lectures given by two Slovenian professors and three Iranian. Dr. Bojan Žalec presented the problems of Islamism and Islamophobia in Europe in the lecture Obstacles in the Way of Dialogue and Peaceful Coexistence: Islamism and Islamophobia, and dr. Tadej Streh-

\footnotetext{
${ }^{32}$ Urška FLISAR, The Influence of Bosnian Islam on the Identity of Slovenian Muslims, Edinost in dialog, 74 (2019) 2, 181-193, 182.
} 
ovec gave a presentation on Religion and Family: Two Sources of Ethics. The Center also introduced Slovenians to the Declaration of the Iranian Religious Leader on Youth Against Extremism titled Message of Ayatollah Seyyed Ali Khamenei to Youth in Europe and North America. The Iranian organizers took the Slovenian Delegation to Qum, $100 \mathrm{~km}$ away from Teheran, where there is the religious center of Iranian Shi'ism with a large pilgrimage sanctuary. Slovenians were guests of the Dean of the Islamic Research Institute there, and then they went to the University for Religions and Religion Denominations, where two plenary lectures were given by one Iranian and one Slovenian. Dr. Mari Jože Osredkar outlined the foundations and reasons for Catholic interreligious dialogue in a lecture titled Reasons for Dialogue between Muslims and Catholics Based on Catholic Teaching. The fruit of this collaboration was the participation of Iranian theologians at the scientific conference of 800 Years of Convivence, October 1-3, 2019 in the Franciscan friary at Tromostovje, Ljubljana. Finally, it should be emphasized that two Iranian students also enrolled in the third level of study at the Faculty of Theology in Ljubljana..$^{33}$ On the third level of dialogue, Osredkar is active in the Commission for Ecumenism and Interreligious Dialogue in the Slovenian episcopal conference and in the Section for Interreligious Dialogue of the Evangelization and Culture Commission of the Bishops' Conferences of Europe.

\section{Conclusion}

Francis of Assisi remains a sign of hope for all humanity today. His message that dialogues in the world is possible and very relevant to our time. Just as, in the midst of the Crusades, the Poor Man from Assisi went unarmed, with only the Gospel in his hand, among the enemies of the Christians at the time, so the Franciscans are invited to shake hands with those who believe differently from them. If Christ answered today the question of "who are my neighbors" (cf. Lc 10:29), He would without a doubt speak of the Muslim refugees in the Christian world. Only in this case, the Gospel doctrine truly brings life, as it teaches »Whenever you did it for any of my people, no matter how unimportant they seemed, you did it for me. « (Mt 25:40) The »other « is »every other« or it is not the Other (God). This means that a Christian must recognize Christ in every person, or he is not a Christian.

In the doctrine of the last Council of the Catholic Church, there are not just paragraphs that one likes, and others one can reject. No! Within this doctrine is the essence of the Gospel; and herein lies the essence of the doctrine of Christ. The last council accepted the principle of dialogue, because the Council

${ }^{33}$ Cf. Mari Jože OSREDKAR, Obisk delegacije Teološke fakultete na Centru za medreligijski dialog, Bogoslovni vestnik, 76 (2016)1, 221-223. 
Fathers realized that this is the heart of the Gospel, and that only in dialogue coexistence and survival are possible. There were enough crusades and too many people killed on all sides. It is true that more and more Muslims live among Christians. In some ways, even today, there is a struggle for supremacy between the two religions. Nevertheless, there is only one way, through which both sides can win, and that is dialogue.

\section{Mari Jože Osredkar* \\ Nastojanje slovenskih franjevaca oko dijaloga s muslimanima \\ Sažetak}

Polazna su točka članka katolički teološki temelji za međureligijski dijalog, o čemu je riječ u prvom poglavlju. Dokumenti Drugog vatikanskog koncila nadahnuli su papu Franju da slijedi primjer sv. Franje Asiškoga, čije je ime izabrao kada je postao papa. Za vrijeme pohoda Abu Dabiju 2019. godine, papa Franjo imao je misu na Arapskom poluotoku te je muslimanskim vođama rekao da dolazi k njima u posjet kao brat. Tom su prigodom papa i veliki imam egipatskog islamskog sveučilišta potpisali Dokument o ljudskom bratstvu za svjetski mir i zajednički život, gdje su napisali da su kršćani i muslimani stvoreni kao djeca Božja te su pozvali sve narode da se, usprkos nekim razlikama, međusobno uvažavaju i rade za mir. Uvjereni smo da je začetnik dijaloga između manje braće i muslimana sv. Franjo Asiški. On je prije 800 godina imao miroljubiv susret sa sultanom Al-Kamilom u Damietti u Egiptu. Taj se susret odvio u prijateljskim okolnostima međusobnog uvažavanja i prihvaćanja. Sjećanje na taj događaj daje nam snagu da razmišljamo o dijalogu između slovenskih franjevaca i muslimana u sadašnjem vremenu. Cilj ovog članka jest predstavljanje djelovanja franjevaca u Sloveniji u odnosima s muslimanima.

Ključne riječi: Franjo Asiški, kršćansko-muslimanski dijalog, međureligijski dijalog, papa Franjo, slovenski franjevci.

(na hrv. prev. Mario Zrakić)

\footnotetext{
* Doc. dr. sc. Mari Jože Osredkar, Sveučilište u Ljubljani, Teološki fakultet, Poljanska 4, SI-1000 Ljubljana, Slovenija; e-mail: mari.osredkar@teof.uni-lj.si.
} 